\title{
IgA Nephropathy, $\beta$ Thalassemia Minor, Psychosis and Deafness: A New Syndrome?
}

Sanda Mrabet ${ }^{1}$, Latifa Bourkhis ${ }^{1}$, Soumaya Ben Abdelkarim² ${ }^{2}$ Awatef Azzabi ${ }^{1}$, Dorsaf Zellama' ${ }^{1}$, Safa Nouira', Wissal Sahtout ${ }^{1}$, Yosra Guedri ${ }^{1}$, Moncef Mokni ${ }^{2}$ and Abdellatif Achour ${ }^{1}$

${ }^{1}$ Department of Nephrology, Dialysis and transplantation, Sahloul University Hospital, Sousse, Tunisia

${ }^{2}$ Department of Pathology, Farhat Hached University Hospital, Sousse, Tunisia

\begin{abstract}
A 43-year-old male was admitted to our hospital because of renal failure and arterial hypertension. He was followed from the age of 15 years for psychosis and had no familial history of disease. Investigations revealed sensorineural deafness, a microcytic hypochromic anemia with normal ferritin leading to the diagnosis of $\beta$ thalassemia minor and nephrotic syndrome. Examination of the renal biopsy specimen demonstrated severe $\lg A$ nephropathy. No classic cause of IgA nephropathy was found. Review of literature showed two previous reported cases of Ig A nephropathy associated with $\beta$ thalassemia minor but without deafness or psychosis. We wonder through this case if an explanation to this association may be made by a genetic defect.
\end{abstract}

Keywords: IgA nephropathy; Minor $\beta$ thalassemia; Psychosis; Deafness

\section{Introduction}

IgA nephropathy (IgA N) is an immune complex-mediated glomerulonephritis defined morphogically by the constant presence of dominant or codominant mesangial deposists of IgA accompanied by a variety of histopathological lesions [1]. It is the most common pattern of primary glomerulonephritis seen in the world $[2,3]$ and represents a significant cause of renal insufficiency in young adults [4]. In the majority of cases the cause remains unknown. There is an increasing literature reporting associations between IgAN and other diseases. Whether these reports represent chance associations or genuine shared pathophysiology is discussed. We report here an association of $\operatorname{IgA}$ Nephropathy with $\beta$ thalassemia minor, psychosis and deafness. We wonder about a genetic explanation to this association.

\section{Case report}

A 43-year-old male was admitted to our hospital because of renal failure. He was followed since the age of 15 years because of psychosis treated by neuroleptic and carbamazepine. He had no history of familial pathology. One month prior to admission, he was admitted to a local clinic with headaches caused by a severe hypertension. He was then referred to our center because of discovery of renal failure with a serum creatinine level at $449 \mu \mathrm{mol} / \mathrm{l}$. At admission, the patient was cooperating and we noticed hearing loss. On physical examination his body mass index was $23 \mathrm{~kg} / \mathrm{m}^{2}$, blood pressure was $180 / 120 \mathrm{mmHg}$ and pulse rate $85 / \mathrm{min}$. Heart sounds were normal. No crackles were heard over the lungs. The abdomen was normal without hepatosplenomegaly. There were no edema in the legs.

Laboratory data at admission were: leukocyte count $7,300 / \mathrm{mm}^{3}$, hemoglobin $7.8 \mathrm{~g} / \mathrm{dl}$, VGM 62, 3, platelet count 318,000/mm3and prothrombin time $34 \mathrm{sec}(79 \%)$. Serum total protein was $5 \mathrm{~g} / \mathrm{dl}$ (including 12, 8\% $\gamma$-globulin), albumin $2.5 \mathrm{~g} / \mathrm{dl}$, glutamic oxalacetic transaminase $16 \mathrm{IU} / 1$, glutamic pyruvictransaminase $11 \mathrm{IU} / 1$, y-glutamyl transpeptidase $38 \mathrm{IU} / 1$, cholinesterase $69 \mathrm{IU} / 1$, creatinine $453 \mu \mathrm{mol} / \mathrm{l}$, blood urea nitrogen $20.4 \mathrm{mmol} / \mathrm{l}$, blood uric acid $604 \mu \mathrm{mol} / \mathrm{l}$, serum ferritin $137 \mathrm{ng} / \mathrm{ml}$, serum iron $11 \mu \mathrm{mol} / \mathrm{l}$. Serum complements were normal. Tests for antigen of hepatitis virus $B$ and serum antibody of hepatitis virus $\mathrm{C}$ were negative. The antinuclear antibody, anti-DNA antibody, anti-neutrophil cytoplasmic antibody and anti-glomerular basement membrane antibody were negative. Electrophoresis of hemoglobin was requested to microcytic anemia with normal serum ferritin and made the diagnosis of $\beta$ thalassemia minor with $\mathrm{Hb}$ A rate at $93.7 \%, \mathrm{Hb} F$ rate at $0.7 \%$ and $\mathrm{Hb} \mathrm{A}_{2}$ rate at $5.6 \%$. The 24 -hour urinary excretion of total protein was $4.48 \mathrm{~g} / \mathrm{d}$. The urine sediment showed many red blood cell casts per high power field. The creatinine clearance was $19 \mathrm{ml} / \mathrm{min} / 1.73 \mathrm{~m}^{2}$.The findings of X-ray, abdominal ultrasound and retrograde urethrocystography were normal. The impedance found bilateral sensorineural hearing loss.

Needle renal biopsy was performed 5 days after admission. Light microscopic examination demonstrated partial fibrosis in the 15 collected glomeruli with cellular or fibrous crescents in three of them (Figure 1) associated to a large interstitial fibrosis, tubular atrophy and thickening of the vascular wall (Figure 2). Immunofluorescence studies revealed $2+$ staining for IgA in the mesangial area (Figure 3 ).

Based on these findings, the patient was diagnosed with Ig A nephropathy and $\beta$ thalassemia minor. Chronic kidney failure was already advanced and end-stage was reached after 6 months follow-up. The patient is currently in chronic hemodialysis.Family survey found no similar case.

\section{Discussion}

Since the original description of the glomerulopathy, idiopathic IgAN has received the bulk of attention in the medical literature, but many diseases have been reported that are sporadically associated with mesangial IgA deposition. Those are dominated by SchonleinHenoch purpura and liver diseases [6]. No classic cause of IgAN was found in our patient. Reviewing the literature, 2 published studies had confirmed IgAN by renal biopsy in $2 \beta$-thalassemia minor patients with microscopic hematuria $[7,8]$ although glomerulonephritis has not been

*Corresponding author: Sanda Mrabet, Department of Nephrology, Dialysis and Transplantation, Sahloul hospital, Sousse, Tunisia, Tel: +216 54595 239; Fax: +216 73367 451; E-mail: snaiida@yahoo.fr

Received: May 14, 2015; Accepted: February 17, 2016; Published: February 24, 2016

Citation: Mrabet S, Bourkhis L, Abdelkarim SB, Azzabi A, Dorsaf Zellama et al (2016) IgA Nephropathy, $\beta$ Thalassemia Minor, Psychosis and Deafness: A New Syndrome?. J Nephrol Ther 6: 237. doi:10.4172/2161-0959.1000237

Copyright: $\odot 2016$ Mrabet S, et al. This is an open-access article distributed under the terms of the Creative Commons Attribution License, which permits unrestricted use, distribution, and reproduction in any medium, provided the original author and source are credited. 


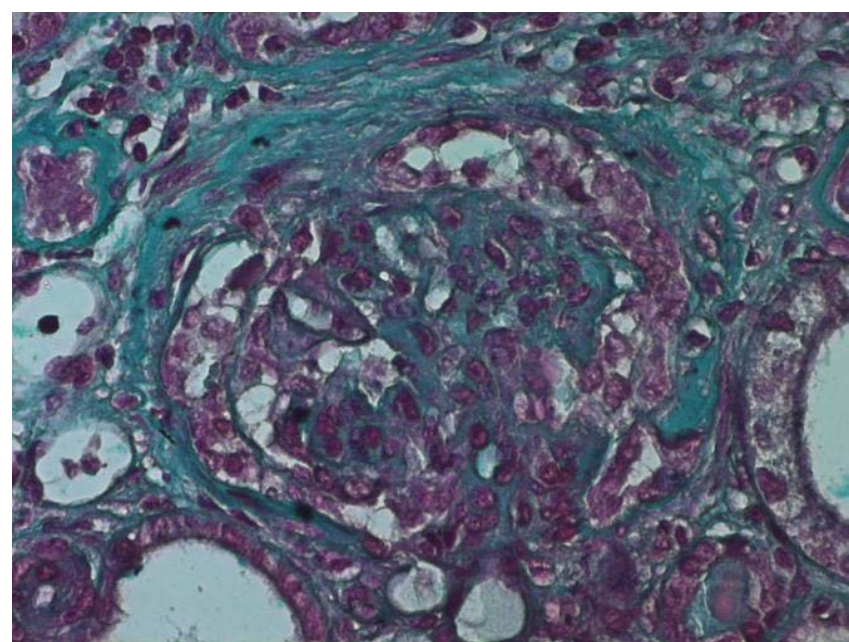

Figure1: Partially fibrotic glomeruli with cellular crescent (Masson's trichrome, $400 \mathrm{x}$ ).

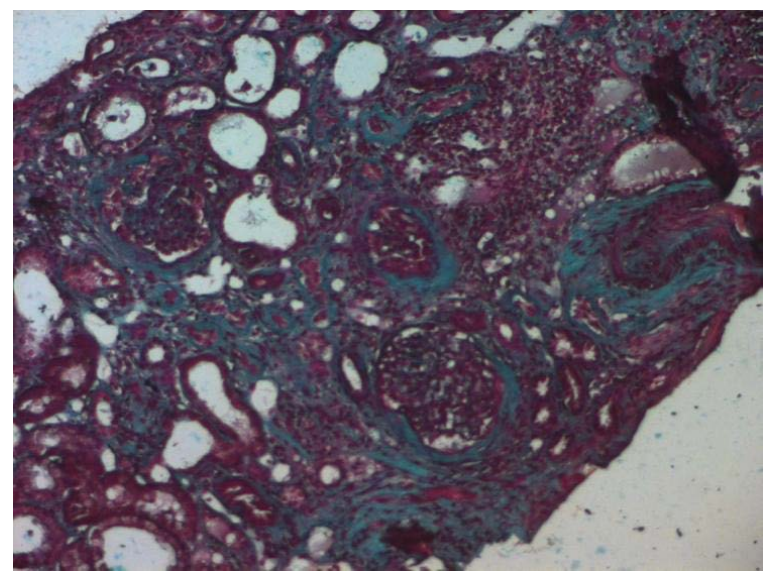

Figure 2: Interstitial fibrosis, tubular atrophy and thickening of the vascular wal (Masson's trichrome, $400 \mathrm{x}$ ).

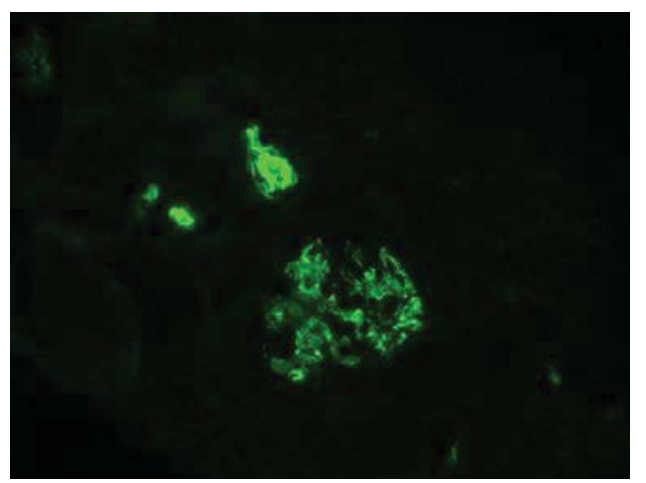

Figure 3: Mesangial IgA deposits on immunofluorescence $(400 \mathrm{x})$

considered to play a critical role in microscopic hematuria associated with thalassemia. Indeed, Microscopic hematuria, frequently observed in thalassemia patients is considered to be the result of tubular damage induced by iron deposition, hypercalciuria, hyperuricosuria, and deferoxamine [9].
In humans and other primates, the elimination process of immune complexes in the liver or spleen, which is important to their removal from circulation, requires in part their binding to erythrocytes through complement receptors [10]. Importantly, erythrocyte complement receptors exhibit genetic polymorphisms. Moreover, a high expression level of erythrocyte complement receptors enhances the formation of rosettes, which is associated with severe malaria such as cerebral malaria. Interestingly, populations in malaria-endemic regions exhibit very low complement receptor 1 expression levels [11], which can be advantageous from an evolutionary point of view. However, the low expression of erythrocyte complement receptors would compromise immune complex clearance. IgAN is an immune complex-mediated disease characterized by impairment of phagocytic function and the presence of abnormal IgA immune complexes in circulation and in the glomerular mesangium. In thalassemia patients, compromised elimination of the circulatory immune complex could lead to IgA.

IgA nephropathy might therefore be explained by its association with $\beta$ - thalassemia minor in our patient, but how to explain his psychosis and sensorineural hearing loss? An explanation for the concomitant occurrence of the abnormalities in our patient could be provided by tetraspanins, a family of membrane proteins found in all multicellular eukaryotes which display numerous properties that indicate their physiological importance in cell adhesion, motility, activation and proliferation, as well as their contribution to pathological conditions such as metastasis or viral infection.CD151, the first member of tetraspanin (TM4) superfamily, has a wide cell and tissue distribution, including epithelium, endothelium, muscle, renal glomeruli and proximal and distal tubules, Schwann cells and dendritic cells, with a single RNA species observed in most human adult tissues [12]. Karamatic et al. [13] examined CD151 in 3 MER2-negative patients ( 2 are sibs) of Indian Jewish origin with end stage kidney disease. In addition to hereditary nephritis, the sibs had sensorineural deafness, pretibial epidermolysis bullosa and minor $\beta$-thalassemia. Karamatic's patients presented with nephrotic syndrome, kidney biopsy showed no apparent abnormalities under light microscopy; immunofluorescence was negative and Electron microscopy, however, showed splitting of the tubular basement membrane and thickening, reticulation and fragmentation of the lamina densa of the glomerular basement membrane with inclusion of electron dense particles. CD151 associates with $\alpha 3$ and $a 6$ during biosynthesis. Abnormal basement membranes in these patients might result from the absence of this association and consequent failure to transport $\alpha 3 \beta 1$ and $\alpha 6 \beta 1$ to the plasma membrane. Karamatic et al. concluded that CD151 is essential for the proper assembly of the glomerular and tubular basement membrane in kidney, has functional significance in the skin, is probably a component of the inner ear, and could play a role in erythropoiesis [13].

Some similarities are found between our patient and those of Karamatic et al. Psychosis may be explained in our case by the distribution of CD151 in nerve cells. These findings leaded us to believe that the combination of different abnormalities in our patient is not a simple coincidence and to believe that the pathology presented by your patient has a genetic susbstratum. However, the involvement of CD 151 remains hypothetical and a genetic defect factor based on tetraspanins or not could explain his presentation [13].

\section{Conclusion}

This case suggests a link between IgA nephropathy, thalassemia minor, psychosis and sensorineural hearing loss. Probably a yet unidentified genetic factor could have an anatomical or functional role in the kidney, nervous system, inner ear, and also plays a role in 
Citation: Mrabet S, Bourkhis L, Abdelkarim SB, Azzabi A, Dorsaf Zellama et al. (2016) IgA Nephropathy, $\beta$ Thalassemia Minor, Psychosis and Deafness: A New Syndrome?. J Nephrol Ther 6: 237. doi:10.4172/2161-0959.1000237

erythropoiesis. Other studies could help to define a syndrome from all these anomalies.

\section{References}

1. Droz D (1976) Natural history of primary glomerulonephritis with mesangial deposits of IgA. Contrib Nephrol 2: 150-157.

2. D'Amico G (1987) The commonest glomerulonephritis in the world: IgA nephropathy. Q J Med 64: 709-727.

3. Wyatt RJ, Julian BA (2013) IgA nephropathy. N Engl J Med 368: 2402-2414.

4. Kiryluk K, Julian BA, Wyatt RJ, Scolari F, Zhang H, et al. (2010) Genetic studies of IgA nephropathy: past, present, and future. Pediatr Nephrol 25: 2257-2268.

5. Pouria S, Barratt J (2008) Secondary IgA nephropathy. Semin Nephrol 28: 27 37.

6. Donadio JV, Grande JP (1997) Immunoglobulin A nephropathy: a clinical perspective. J Am Soc Nephrol 8: 1324-1332.

7. Harada T, Ozono Y, Miyazaki M, Yamaguchi K, Kanamoto Y, et al. (1994) Association of IgA nephropathy and beta-thalassemia. Clin Nephrol 41: 181-182.
8. Kang JH, Park BR, Kim KS, Kim do Y, Huh HJ, et al. (2013) Beta-thalassemia minor is associated with IgA nephropathy. Ann Lab Med 33: 153-155.

9. Aldudak B, Karabay Bayazit A, Noyan A, Ozel A, Anarat A, et al. (2000) Renal function in pediatric patients with beta-thalassemia major. Pediatr Nephrol 15 109-112.

10. Hebert LA, Cosio G (1987) The erythrocyte-immune complex-glomerulonephritis connection in man. Kidney Int 31: 877-885.

11. Sinha S, Jha GN, Anand P, Qidwai T, Pati SS, et al. (2009) CR1 levels and gene polymorphisms exhibit differential association with falciparum malaria in regions of varying disease endemicity. Hum Immunol 70: 244-250.

12. Sincock PM, Mayrhofer G, Ashman LK (1997) Localization of the transmembrane 4 superfamily (TM4SF) member PETA-3 (CD151) in normal human tissues: comparison with CD9, CD63, and alpha5beta1 integrin. J Histochem Cytochem 45: $515-525$

13. Karamatic Crew V, Burton N, Kagan A, Green CA, Levene C, et al. (2004) CD151, the first member of the tetraspanin (TM4) superfamily detected on erythrocytes, is essential for the correct assembly of human basement membranes in kidney and skin. Blood 104: 2217-2223. 